\title{
Analisis Kesalahan Gaya Berbahasa Pada Sosial Media Instagram dalam Caption dan Komentar
}

\author{
Umi Kholifah $^{1}$ dan Atiqa Sabardila ${ }^{2}$ \\ Fakultas Keguruan dan Ilmu Pendidikan, Universitas Muhammadiyah Surakarta \\ a310180140@student.ums.ac.id, dan as193@ums.ac.id
}

\begin{abstract}
The use of language on social media on Instagram as a means of daily communication, one of which is to comment and text. Various languages are used in communication, including Indonesian, regional languages, various languages, and foreign languages. This study aims to describe the form of misuse of Indonesian on Instagram and to describe the forms of misunderstanding of the use of Indonesian on Instagram. This research method uses qualitative descriptive because in this study the researcher identifies language errors that are on social media, especially on Instagram. The results showed the ineffectiveness of language users carried out by Instagram social media users in the form of using Indonesian, (1) spelling errors (2) use of diction (3) grammatical structural errors. There are also forms of misunderstanding in the use of Indonesian on Instagram (1) variations of Indonesian and English (2) variations of Indonesian with slang, English, local languages.
\end{abstract}

Keywords: Language misunderstanding; social media; various languages.

\section{Intisari}

Penggunaan bahasa yang berada disosial media instagram sebagai alat komunikasi dalam sehari-hari salah satunya untuk berkomentar dan penulisan caption. Berbagai bahasa yang digunakan dalam komunikasi antara lain Bahasa Indonesia, bahasa daerah, ragam bahasa, dan bahasa asing. Penelitian ini bertujuan untuk mendeskripsikan wujud kesalahan penggunaan bahasa Indonesia di instagram dan untuk mendeskripsikan bentuk variasi kesalahpahaman penggunaan bahasa indonesia di instagram. Metode penelitian ini menggunakan kualitatif yang bersifat deskriptif karena dalam penelitian ini peneliti untuk mengidentifikasi kesalahan bahasa yang berada media sosial terutama di instagram. Hasil penelitian menunjukan ketidak efektifan dalam pengguna bahasa yang dilakukan oleh pengguna media sosial instagram pada wujud penggunaan bahasa Indonesia adanya (1) kesalahan ejaan (2) pemakaian diksi (3) kesalahan struktur tata bahasa. Ada juga bentuk kesalahpahaman dalam penggunaan bahasa Indonesia di instagram (1) variasi bahasa Indonesia dan bahasa Inggris (2) variasi bahasa Indonesia dengan bahasa gaul, bahasa Inggris, bahasa daerah setempat.

Kata-kunci: Kesalahpahaman bahasa; media sosial; ragam bahasa.

\section{Pendahuluan}

Penggunaan bahasa memiliki peranan dalam berkomunikasi setiap hari. Bahasa Indonesia merupakan bahasa sangat yang efektif untuk dipergunakan setiap berkomunikasi. Setiap aktivitas baik secara langsung maupun di media sosial. Dengan adanya komunikasi banyak 
sekali pilihan dan semakin canggih dalam mengungkapkan sesuatu kata atau kalimat, sehingga menimbulkan banyak kesalahan dalam penggunaan bahasa Indonesia di zaman sekarang.

Teknologi merupakan salah satu alat yang mempermudah kegiatan atau aktivitas manusia. Internet ini dapat di akses di mana saja serta kapanpun dilakuan oleh seseorang tidak mengenal umur baik dari anak-anak, remaja, dewasa, lansia dengan leluasa. Kebahasaan dalam menggunakan media sosial dan memberikan potensi masyarakat dalam mengekspresikan maksud dan tujuan dari pengguna. Pengguna tidak hanya berkomunikasi untuk menyapa, memuji, kirim foto, video saja. Namun juga memberikan komentar komentar yang cukup aneh adalah instagram. Dalam hal tersebut saya sebagai penulis mendeskripsikan wujud kesalahan penggunaan bahasa Indonesia di instagram.

Instagram merupakan media yang sering terdapat dengan fitur yang berfokus pada gambar dan video, tidak seperti facebook yang lebih dahulu muncul memiliki fitur lebih bebas dan lebih fleksibel dalam penggunaan. Gambar dan video yang sering di publikasikan oleh pengguna akun di instagram biasanya disertai status (caption) ini yang menjelaskan gambar dan video yang diunggah dalam akun tersebut. Sering dijumpai dalam pengguna akun di instagram menemukan kata-kata ataupun kalimat yang dalam instagram melenceng dari bahasa Indonesia ini sebagai wujud mendeskripsikan bentuk variasi kesalahpahaman penggunaan bahasa Indonesia di instagram sebagai masalah yang sering terjadi.

Berdasarkan uraian di atas maka, permasalahan dalam penelitian ini adalah bagaimana wujud kesalahan dalam penggunaan bahasa Indonesia dan bagaimana bentuk barisi kesalahpahaman di instagram. Pambajeng (2018) menjelaskan bahwa gaya bahasa merupakan suatu penggunaan bahasa yang bisa dikatakan kasar dan halus, karena pengunaan saat penulisan caption warga net tidak memperdulikan apa akibat dalam penulisan. Terdapat pengguna media sosial salah satunya penggunaan instagram yang menggunakan bahasa kasar serta bahasa yang tidak patut untuk dipertontonkan di ranah publik. Walaupun pengguna tahu bahwa bahasa digunakan kasar mereka masih saja tetap digunakan dalam berkomentar dan caption. Bahasa yang kasar bukan hanya digunakan dalam sosial media melainkan dalam komunikasi secara langsung.

Berbahasa dengan menggunakan ragam bahasa gaul ini dijadikan sebagai bahasa sehari-hari. Bahkan berbagai kalangan umur menjadikan akun instagram sebagai media curahan hati atau cemoohan melalui sosial media tanpa memperdulikan efek yang 
ditimbulkan nanti kedepannya. Bukan hanya menggunakan ragam bahasa saja melainkan menggunakan bahasa asing seperti bahasa inggris yang sering dicampurkan dengan bahasa Indonesia atau bahasa daerahnya masing - masing. Terdapatnya wujud kesalahan didalam berbahasa atau penulisan dalam caption dan berkomentar ini sering diabaikan dengan penggunaan ejaan, diksi serta dalam struktur tata bahasa.

Kadek Wirahayuni (2019) meneliti "Penilikan Kesalahan Berbahasa Indonesia yang Baik dan Benar dalam Konteks Sosial - Masyarakat Di Raung Publik". Penemuan tujuan dari penelitian ini adalah untuk meminimalkan kesalahan berbahasa Indonesia di ruang publik dalam konteks sosial - kemasyarakatan perlu upaya yang dilakukan yakni masyarakat hendaknya peduli dengan bahasa Indonesia. Persamaan penelitian ini adalah berdasarkan penelitiannya, kesalahan berbahasa Indonesia di ruang publik tersebut ternyata masyarakat tidak begitu memperdulikan. Mereka berpendapat hal tersebut tidak begitu berpengaruh terhadap pengertian dari tulisan yang tercantum. Mereka masih tetap mengerti dengan maksud tulisan salah 78\% masyarakat tidak tahu jika ada beberapa penulisan yang tidak baku di ruang publik. Perbedaan dalam penelitian ini adalah menekankan pada ruang publik seperti kesalahan poster yang diunggah di media sosial instagram sedangkan penelitian saya menekankan pada kesalahan caption dan komentar di instagram

Lilis Amaliah Rosdiana (2019) meneliti "Ketidakefektifan Kalimat Pada Caption Instagram Mahasiswa Fakultas Pertanian Universitas Winaya Mukti”. Penemuan penelitian ini adalah untuk mendeskripsikan suatu gambaran ketidakefektifan dalam kesalahan penulisan caption. Persamaan dalam penelitian ini terdapat adanya analisis penulisan caption instagram yang menunjukan perbaikan kata dalam caption dan komentar. Serta adanya pencampuran kata bahasa indonesia dengan bahasa asing serta adanya pleonasme dalam caption. Perbedaan dalam penelitian ini adalah penelitian ini menjelaskan ketidakefektifan kalimat lebih mendominasi caption di instagram sedangkan penelitian saya menekankan pada wujud kesalahan serta variasi bahasa.

Kartika Tiara Syarifudin (2018) meneliti "Pembentukan Kosa kata Baru Sebagai Bentuk Coinage Dalam Media Sosial Instagram". Penemuan peneliti ini menentukan dan pembentukan kata yang terdapat di instagram serta pembentukan adanya karakter pada caption dan komentar di instagram. Persamaan penelitian ini adalah terdapatnya bahasa yang baru dan dijadikan sebagai acuan bahasa sehari - hari dan terdapatnya bahasa gaul ini satu pokok terjadinya bahasa atau kosa kata. Perbedaan ini terdapat pada data yang diambil yaitu menggunakan tagar karena netizen sering menggunakan hastag dalam suatu caption 
untuk menyebar luaskan pada tagar tersebut. Tagar yang sering digunakan ini biasanya berupa kata dalam suatu benda. Sedangkan penelitian saya menekankan pada data suatu caption dan komentar yang salah dalam berbahasa disosial media instagram.

Saidathun Nafisah (2020) meneliti "Pembentukan Kata Pada Istilah Khas di Instagram dengan Unsur Bahasa Inggris” penemuan ini menemukan kata dalam bisnis online yang mengandung unsur bahasa Inggris, untuk pembentukan istilah - islitah pada instagram dan mengetahui implikasi munculnya istilah - istilah terhadap situasi kebahasaan di Indonesia. Hasil penelitian ini terdapat sejumlah kata khas instagram yang didalamnya memuat unsur bahasa Inggris. Kata-kata tersebut terbentuk dari kombinasi bahasa antara Persamaan dalam penelitian ini dilihat dari proses pembentukan kata paling banyak ditemukan mengunakan pembentukan istilah khas yang berbeda-beda dalam bahasa asing. Kosa kata khas yang ditemukan dan dibahas dalam penelitian masih terbatas pada register tertentu. Perbedaan ini terdapat pada tidak adanya pencampuran bahasa asing dengan bahasa daerah yang ada di Indonesia.

Margareta Evi Yuliana (2019) meneliti "Penggunaan Kata Tidak Baku di Media Sosial Instagram" penemuan penelitian ini untuk mengetahui penggunaan bahasa dan pilihan kata berubah menarik dan mengetahui kata tidak baku di media sosial khususnya pada salah satu akun instagram dengan caption dan komentar. Terdapatnya kesalahan dalam penggunaan bahasa yaitu kesalahan penulisan kata tidak baku. Kata tidak baku ini masih berubah dominan dalam penggunaan kebahasan dalam penyampaikan informasi. Ketidakbakuan ini karena adanya terdapatnya bahasa daerah dengan bahasa asing yang tidak sesuai dengan kaidah yang ditetapkan.

Hari kusmanto (2019) meneliti "Ketidaksopanan Berkomentar Pada Media Sosial Instagram: Studi Politikopragmatik". Penemuan penelitian ini untuk mendiskripsiakan adanya bentuk-bentuk ketidaksopanan netizen dalam akun instagram yang tertuju pada komentar. Ketidaksopanan ini terjadi karena penulisan bahasa yang kasar seperti menghina, menegejek serta berbicara yang kotor. Dalam hal ini penggunaan bahasa di kolom komentar banyak terdapat kata atau kalimat yang keluar dari adab kesopanan. Mereka menggunakan kata dan bahasa yang tidak sopan selayaknya tidak mengertinya tindak tutur. Tidak mengenal umur adanya anak-anak, remaja, tua dalam berkomentar di media sosial.

Pambajeng Yudo Handoyo (2018) meneliti “Gaya Bahasa Dan Komentar Dalam Akun Instagram (Mimi Peri Rapunchelle)”. Penemuannya mengungkapan suatu gaya 
bahasa dalam komentar dan caption pada pikiran dan kepribadian seseorang. Terdapatnya komentar yang kasar dalam menghakimi serta mejelekkan seseorang secara langsung di tuai di instagram salah satu akun. Hari kusamanto, dkk. (2019) meneliti "Realisasi Kesatuan Berkomunikasi Pada Media Sosial instagram @Jokowi: Studi Politikpragmatik”. Penemuannya wujud kesantunan yang digunakan followers Jokowi memiliki perhatian terhadap kepemimpinan yang dilakukan jokowi dan memiliki tingkat kepedulian yang tinggi terhadap jokowi sebagai pemimpin. Daya memuji, daya mendukung, daya memengaruhi, daya memotivasi dan daya menyarankan hal ini ditunjukan followers Jokowi.

\section{Metode Penelitian}

Metode penelitian ini menggunakan pendekatan kualitatif yang bersifat deskriptif kualitatif. Data penelitian ini bersumber dari penggunaan media sosial yang dilakukan dengan menganalisis caption dan komentar melalui media instagram yang digunakan sebagai media komunikasi bertukar pikiran pada seseorang. Penelitian yang ditulis ini berkaitan dengan analisis penggunaan gaya bahasa pada media instagram. Sumber data merupakan bahan, sebagai acuan yang digunakan dalam penelitian. Sumber data dalam penelitian ini adalah caption dan kolom komentar di instagram. Peneliti dapat mengetahui ketidak efektifan dalam pengunaan bahasa yang dilakukan oleh pengguna media sosial instagram pada wujud penggunaan dan kesalahpahaman bahasa Indonesia.

Teknik pengumpulan data yang digunakan adalah teknik bebas simak dan teknik catat (Saputra, 2016) Teknik ini diterapkan untuk memperoleh data secara langsung dari objek penelitian dengan mencari data pada media instagram untuk mengklasifikasi data yang relavan. Data diambil dari beberapa caption dan komentar di instagram yang mengenai kesalahan berbahasa.

\section{Hasil dan Pembahasan}

1. Mendeskripsikan wujud kesalahan penggunaan bahasa Indonesia di instagram. Dalam penggunaan bahasa Indonesia masih terdapatnya kesalahan dalam berbahasa seperti pada caption dan komentar warganet pada akun instagram masing - masing. Seiring berjalannya waktu banyak sekali variasi bahasa yang digunakan masyarakat dalam mengungkapkan kata - kata ataupun kalimat yang dituang dalam media sosial. Dengan lalainya bahasa sering kali menggunakan kesalahan penggunaan kata-kata yang ejaan, pemakaian diksi, struktur tata bahasa, dan bahasa campuran misal bahasa 
Indonesia dicampur dengan bahasa Inggris. Dalam pengungkapannya dalam instagram netizen bisa sesuka hati dalam berkomentar tanpa memperdulikan efek yang dijadikan setelah mengungkapkan bahasa yang digunakannya setiap unggahan.

Wujud kesalahan penggunaan bahasa Indonesia antara lain:

a. Kesalahan Ejaan

Penggunaan bahasa Indonesia seharusnya berpedoman dengan kaidah ejaan yang disempurnakan (EYD) ini salah satu faktor hal yang sangat penting dalam menulis. Penggunaan bahasa pada caption dan komentar sosial media instagram biasanya terdapat kesalahan karena dalam proses penulisan caption dan komentar tidak berpedoman pada kaidah bahasa yang benar.

Data analisis kesalahan ejaan.

\begin{tabular}{|c|c|c|c|}
\hline No Data & kalimat & Kesalahan kalimat & Keterangan \\
\hline Data 1 & $\begin{array}{l}\text { Postingan caption } \\
\text { @Tiara } \\
\text { SELAMAT ULANG } \\
\text { TAHUN, semoga } \\
\text { panjang umur, sehat } \\
\text { selalu, murah rezeki }\end{array}$ & $\begin{array}{l}\text { SELAMAT ULANG } \\
\text { TAHUN }\end{array}$ & $\begin{array}{lr}\text { Analisis } & \text { kesalahan } \\
\text { tersebut adalah dalam } & \text { denggunaan } \\
\text { kapital tidak digunakan } \\
\text { seluruhnya } & \text { dalam } \\
\text { sebuah kalimat. } & \end{array}$ \\
\hline Data 2 & $\begin{array}{l}\text { Komentar@sukmahps } \\
\text { iNi nAtuRal gA pAke } \\
\text { LipEn tAuk }\end{array}$ & $\begin{array}{l}\text { iNi nAtuRal gA } \\
\text { pAke LipEn tAuk }\end{array}$ & \begin{tabular}{lrr} 
Analisis & \multicolumn{2}{c}{ kesalahan } \\
tersebut adalah & dalam \\
penggunaan & huruf \\
kapital. & Penggunaan \\
huruf ini & seharusnya \\
tidak & \multicolumn{2}{c}{ menggukan } \\
kapital karena & sesuai \\
dengan & & kaidah \\
penulisan & & \\
\end{tabular} \\
\hline Data 3 & \begin{tabular}{lr}
\multicolumn{2}{l}{ Komentar } \\
@nikiwahyu \\
Lama-lama kata \\
pemerintah "DAH \\
SERAH LU DAH \\
PADA, W NYERAH", \\
dokter pun angkat \\
tangan saking ngeyel \\
masyarakatnya -,--
\end{tabular} & $\begin{array}{lrr}\text { DAH } & \text { SERAH } & \text { LU } \\
\text { DAH } & \text { PADA, } & \text { W } \\
\text { NYERAH } & \end{array}$ & $\begin{array}{l}\text { Analisis kata tersebut } \\
\text { menggunkan bahasa } \\
\text { gaul. Kata W } \\
\text { maksudnya aku, serta } \\
\text { dalam penggunana } \\
\text { huruf tidak semua } \\
\text { kalimat harus kapital. }\end{array}$ \\
\hline
\end{tabular}

b. Pemakaiaan Diksi 
Penggunaan bahasa pada caption dan komentar ini sering berkaitan dengan kebahasaan. Salah satu kesalahan yang dilakukan pengguna instagram pada caption dan komentar yakni pemakaian diksi pada bahasa yang dituangkan disosial media. Diksi di sini menekankan pada pemilihan kalimat atau kata yang sesuai dengan mengungkapkan kata ataupun kalimat dituang di media sosial media instagram.

Data analisis pemakaian diksi di instagram

\begin{tabular}{|c|c|c|c|}
\hline No Data & Kalimat & Kesalahan kalimat & Keterangan \\
\hline Data 1 & $\begin{array}{l}\text { Postingan@dewipinta } \\
\text { Ma love }\end{array}$ & My love & $\begin{array}{l}\text { tepat struktur } \\
\text { bahasa asing }\end{array}$ \\
\hline Data 2 & $\begin{array}{l}\text { Caption@icukags.s } \\
\text { Ingin ku bertanya pada } \\
\text { rumput yg bergoyang. Tp tek } \\
\text { ra goyang sukete }\end{array}$ & $\begin{array}{l}\text { Tp tek ra goyang } \\
\text { suket e }\end{array}$ & $\begin{array}{l}\text { Kata tersebut } \\
\text { seharusnya diganti } \\
\text { dengan } \\
\text { menggunakan } \\
\text { bahasa Indonesia } \\
\text { "tapi kenapa } \\
\text { rumputnya tidak } \\
\text { bergoyang" }\end{array}$ \\
\hline Data 3 & $\begin{array}{l}\text { Komentar@galih_rizkii } \\
\text { Inginku berkata kasar tp } \\
\text { takut dosa yaaawooh }\end{array}$ & Yaaawooh & $\begin{array}{l}\text { Kata yaaawoh } \\
\text { seharusnya } \\
\text { diaganti dengan } \\
\text { allah }\end{array}$ \\
\hline Data 4 & $\begin{array}{l}\text { Komentar } \\
@ \text { sandhikarafirman } \\
\text { Hukum seberat-beratnya } \\
\text { kalo perlu suntik mati, kui } \\
\text { sapam pekok }\end{array}$ & Kalo, sapam, pekok & $\begin{array}{l}\text { Kata kalo } \\
\text { seharusnya diganti } \\
\text { kalau, kata sapam } \\
\text { diganti dengan } \\
\text { satpam, dan kata } \\
\text { pekok seharusnya } \\
\text { diganti dengan } \\
\text { kata bodoh. }\end{array}$ \\
\hline Data 5 & $\begin{array}{l}\text { Komentar } \\
\text { @erlynda_kasim } \\
\text { Wajar aja yang positif } \\
\text { corona nambah terussssssss }\end{array}$ & terusssssssss & $\begin{array}{l}\text { Penggulangan } \\
\text { huruf seharusnya } \\
\text { tidak dipakai } \\
\text { karena tidak sesuai } \\
\text { dengan kaidah } \\
\text { penulisan } \\
\end{array}$ \\
\hline Data 6 & $\begin{array}{l}\text { Komentar } \\
\text { @prayudi.hidayat } \\
\text { Trs kata corona yg ngelihat } \\
\text { ini baru enakkkk, banyak } \\
\text { mangsa,, }\end{array}$ & $\begin{array}{l}\text { Ngelihat, enakkk,, } \\
\text { mangs,, }\end{array}$ & $\begin{array}{l}\text { Kata "ngelihat" } \\
\text { seharusny diganti } \\
\text { dengan kata lihat } \\
\text { sesuai KBBI. } \\
\text { Tanda koma yang } \\
\text { di gunakan pada } \\
\text { akhir kata serta }\end{array}$ \\
\hline
\end{tabular}




\begin{tabular}{|l|l|l|l|}
\hline & & & $\begin{array}{l}\text { kalimat } \\
\text { pernyataan tidak } \\
\text { sesuai dengan } \\
\text { aturan PUEBI }\end{array}$ \\
\hline Data 7 & $\begin{array}{l}\text { Komentar } \\
\text { @lidyaseptiwidiyawatiberl } \\
\text { Gmn mau segera selesai klo } \\
\text { masih banyak yng kurang } \\
\text { sadar... bahaya covid.... }\end{array}$ & Sadar... covid... & $\begin{array}{l}\text { Tanda titik yang } \\
\text { dipakai pada akhir } \\
\text { kalimat tidak } \\
\text { sesuai dengan } \\
\text { aturan PUEBI }\end{array}$ \\
\hline Data 8 & $\begin{array}{l}\text { Komentar @wianyajeng } \\
\text { Manusiawi koq,,. daripada } \\
\text { menjemput rezeki }\end{array}$ & Koq, & $\begin{array}{l}\text { Kata koq ini } \\
\text { merupakan salah } \\
\text { satu bahasa gaul } \\
\text { yang bisa ditulis } \\
\text { kok dan } \\
\text { penggunaan tanda } \\
\text { koma yang dipakai } \\
\text { pada akhir kata } \\
\text { tidak sesuai } \\
\text { dengan aturan } \\
\text { PUEBI }\end{array}$ \\
\hline
\end{tabular}

c. Kesalahan Struktur Tata Bahasa

Sebagian besar pengguna media sosial intagram kurang memerhatikan kaidah penulisan yang benar. Dalam penyusunan struktur tata bahasa harus benar agar menjadi suatu kalimat yang jelas dan terperinci, sedangkan kesalahan struktur tata bahasa dilakukan pengguna media sosial instagram adalah kelengkapan dalam berbahasa yang sering dilakukan padahal setiap kata memiliki sangkut paut dalam kalimat.

Contoh kesalahan struktur tata bahasa di instagram

\begin{tabular}{|c|c|c|c|}
\hline No Data & Kalimat & $\begin{array}{ll}\text { Jenis } & \text { kalimat } \\
\text { penulisan } & \end{array}$ & Keterangan \\
\hline Data 1 & $\begin{array}{l}\text { Postingan@radotvalent } \\
\text { Gak perlu tenar yang } \\
\text { penting kita main sangar } \\
\text { jangan larut eforia kita fokus } \\
\text { juara }\end{array}$ & eforia & \begin{tabular}{lr} 
Dalam kesalahan \\
kata eforia dengan \\
penulisan yang \\
benar adalah euforia \\
yang $r$ berati \\
seseorang $y a m g$ \\
meiliki perasaan \\
yang gembira \\
bahkan perasaan ini \\
\multicolumn{2}{l}{ bisa lebih. }
\end{tabular} \\
\hline
\end{tabular}




\begin{tabular}{|c|c|c|c|}
\hline Data 2 & $\begin{array}{l}\text { Komentar@dhofira_zuhra } \\
\text { Kita semua harus berhati- } \\
\text { hati jaga adik kita karena } \\
\text { musim penculikan anak }\end{array}$ & Kita semua & $\begin{array}{lr}\text { Dalam } & \text { kesalahan } \\
\text { caption } & \text { tersebut } \\
\text { makna nya kita } \\
\text { semua }\end{array}$ \\
\hline Data 3 & $\begin{array}{l}\text { Caption@itsmeias_- } \\
\text { Bukan ilusi jika kamu nyata, } \\
\text { kalupun nyata mungkin } \\
\text { hanya menjadi ilusi semata }\end{array}$ & ilusi & $\begin{array}{l}\text { Penggunaan kata } \\
\text { yang seharusnya di } \\
\text { ganti dengan angan- } \\
\text { angan. }\end{array}$ \\
\hline Data 4 & $\begin{array}{l}\text { Caption } \\
\text { @kegoblogagarislucu } \\
\text { Sefruit tutorial membuat } \\
\text { lesung pipi }\end{array}$ & sefruit & $\begin{array}{l}\text { Kata sefruit ini kata } \\
\text { penghubung } \\
\text { kalimat }\end{array}$ \\
\hline Data 5 & $\begin{array}{l}\text { Caption@aldi_triyogi } \\
\text { filososfi yang sederhana: isi } \\
\text { bukan berati ada bisa jadi } \\
\text { kosong dan kosong bisa jadi } \\
\text { ada. }\end{array}$ & filosofi & $\begin{array}{lr}\text { Kata filosofi yang } \\
\text { benar adalah filsafat } \\
\text { yang } & \text { berati } \\
\text { mendasari } & \text { alam } \\
\text { pikiran atau } & \text { suatu } \\
\text { kegiatan } & \end{array}$ \\
\hline
\end{tabular}

1. Bentuk Variasi Kesalahpahaman penggunaan Bahasa Indonesia di instagram

a. Variasi bahasa indonesia dan bahasa Inggris

Penulisan caption ada yang menggunakan bahasa Inggris terdapatnya satu kata atau lebih dan dilanjutkan dengan dengan bahasa lain. Terdapatnya caption serta komentar netizen yang tidak menggunakan kaidah PUEBI ataupun KBBI yang sesuai bahasa Indonesia. Banyak sekali netizen yang menggunakan media sosial media dengan menghubungkan Bahasa Indonesia dengan bahasa asing lainya. Salah satu bahasa yang sering digunakan adalah bahasa Inggris, dengan menggunakan bahasa ini banyak masyarakat mengerti dan memahami bahasa tersebut. Bercampurnya bahasa Indonesia dengan bahasa Inggris ini berubah daya tarik tersendiri oleh pembaca.

Contoh analisis pemakaian variasi Bahasa Indonesia dan Bahasa Inggris di instagram.

\begin{tabular}{|l|l|l|l|}
\hline No Data & Kalimat & Kesalahan kalimat & Keterangan \\
\hline Data 1 & Postingan @dewipinta & May love & Terdapatnya \\
& Ma love & & $\begin{array}{l}\text { struktur bahasa } \\
\text { asing dengan } \\
\text { penulisar yang } \\
\end{array}$ \\
& & & salah. \\
\hline
\end{tabular}




\begin{tabular}{|c|c|c|c|}
\hline Data 2 & $\begin{array}{l}\text { Caption@icukags.s } \\
\text { Ingin ku bertanya pada } \\
\text { rumput yg bergoyang. Tp tek } \\
\text { ra goyang sukete }\end{array}$ & $\begin{array}{l}\text { Tp tet ra goyang } \\
\text { sukete }\end{array}$ & $\begin{array}{l}\text { Kata tersebut } \\
\text { seharusnya diganti } \\
\text { dengan } \\
\text { menggunakan } \\
\text { bahasa indonesia } \\
\text { "tapi kenapa } \\
\text { rumputnya tidak } \\
\text { bergoyang" }\end{array}$ \\
\hline Data 3 & $\begin{array}{l}\text { Komentar@galih_rizkii } \\
\text { Inginku berkata kasar tp } \\
\text { takut dosa yaaawooh }\end{array}$ & Yaaawooh & $\begin{array}{l}\text { Kata yaaawoh } \\
\text { seharusnya } \\
\text { diaganti dengan } \\
\text { allah }\end{array}$ \\
\hline Data 4 & $\begin{array}{l}\text { Komentar } \\
@ \text { sandhikarafirman } \\
\text { Hukum seberat-beratnya } \\
\text { kalo perlu suntik mati, kui } \\
\text { sapam pekok }\end{array}$ & Kalo, sapam, pekok & $\begin{array}{l}\text { Kata kalo } \\
\text { seharusnya diganti } \\
\text { kalau, kata sapam } \\
\text { diganti dengan } \\
\text { satpam,dan kata } \\
\text { pekok seharusnya } \\
\text { diganti dengan } \\
\text { kata bodoh. }\end{array}$ \\
\hline Data 5 & $\begin{array}{l}\text { Komentar } \\
\text { @erlynda_kasim } \\
\text { Wajar aja yang positif } \\
\text { corona nambah terussssssss }\end{array}$ & Terussssssss & \begin{tabular}{l}
\multicolumn{2}{l}{ Penggulangan } \\
huruf seharusnya \\
tidak dipakai \\
karena tidak sesuai \\
dengan kaidah \\
penulisan
\end{tabular} \\
\hline Data 6 & $\begin{array}{l}\text { Komentar } \\
\text { @prayudi.hidayat } \\
\text { Trs kata corona yg ngelihat } \\
\text { ini baru enakkkk, banyak } \\
\text { mangsa,, }\end{array}$ & $\begin{array}{l}\text { Ngelihat, enakkk,,, } \\
\text { mangs,, }\end{array}$ & $\begin{array}{l}\text { Kata ngelihat } \\
\text { seharusny diganti } \\
\text { dengan kata lihat } \\
\text { sesuai KBBI. } \\
\text { Tanda titik yang di } \\
\text { pakai pada akhir } \\
\text { kalimat } \\
\text { pernyataan tidak } \\
\text { sesuai dengan } \\
\text { aturan PUEBI }\end{array}$ \\
\hline Data 7 & $\begin{array}{l}\text { Komentar } \\
\text { @ lidyaseptiwidiyawatiberl } \\
\text { Gmn mau segera selesai klo } \\
\text { masih banyak yng kurang } \\
\text { sadar... bahaya covid.... }\end{array}$ & Sadar... covid... & $\begin{array}{l}\text { Tanda titik yang } \\
\text { dipakai pada akhir } \\
\text { kalimat tidak } \\
\text { sesuair dengan } \\
\text { aturan PUEBI }\end{array}$ \\
\hline Data 8 & $\begin{array}{l}\text { Komentar@wianyajeng } \\
\text { Manusiawi koq,,, daripada } \\
\text { menjemput rezeki }\end{array}$ & $\begin{array}{l}\text { manusiawi } \\
\text { Koq,,, }\end{array}$ & $\begin{array}{l}\text { Kata koq ini } \\
\text { merupakan salah } \\
\text { satu bahasa gaul } \\
\text { yang bisa ditulis } \\
\text { kok dan } \\
\text { penggunaan tanda } \\
\text { koma yang dipakai } \\
\text { pada akhir kata }\end{array}$ \\
\hline
\end{tabular}




\begin{tabular}{|l|l|l|l|}
\hline & & & $\begin{array}{l}\text { tidak } \\
\text { dengan }\end{array}$ \\
& & PUEBI & aturan \\
\hline
\end{tabular}

a. Variasi Bahasa Indonesia dengan bahasa gaul, bahasa Inggris dan bahasa daerah setempat

Penggunaan bahasa dalam sosial media ini sangat beragam karena adanya pencampuran bahasa Indonesia, bahasa daerah, bahasa asing. Bercampurnya ketiga bahasa tersebut menumbuhkan berbagai makna. Setiap kalimat atau kata yang memiliki arti tersendiri. Penggunaan bahasa ini dijadikan pada sosial media facebook, instagram, twiter, dll. Hal ini terlihat dari unggahan caption, cerita pada instagram netizen. Netizen disini sering menggunakan Bahasa Indonesia namun sering tidak memperdulikan penggunaan kata. Misal kata "bat" dalam artian ini maksudnya "banget", lalu ada kata "gpp" yang maksudnya "gak papa". Dalam menggunakan kata tersebut nertizen sering menggunakan kata-kata tersebut dalam caption ataupun berkomentar. Bentuk kalimat yang digunakan dalam bahasa gaul ini lebih sederhana dan kosa kata yang mudah dipahami. Bahasa gaul juga sering menggunakan kata yang disingkat karena lebih mudah dalam penulisan. Misalnya kata "sans" maksudnya "santai". Dalam bahasa daerah ini juga berperan dalam penggunaan bahasa di media sosial salah satunya bahasa Jawa, ini dijadikan salah satu penggunaan bahasa yang sering dilakukan oleh pengguna media sosial instagram.

Contoh analisis pemakaian variasi bahasa Indonesia dengan bahasa gaul dan bahasa Inggris dan bahasa daerah setempat.

\begin{tabular}{|c|c|c|c|}
\hline No Data & Kalimat & \begin{tabular}{|l} 
Jenis kalimat \\
penulisan
\end{tabular} & Keterangan \\
\hline Data 1 & $\begin{array}{l}\text { Postingan@radotvalent } \\
\text { Gak perlu tenar yang } \\
\text { penting kita main sangar } \\
\text { jangan larut eforia kita } \\
\text { fokus juara }\end{array}$ & Eforia & $\begin{array}{lr}\text { Dalam } & \text { kesalahan } \\
\text { kata eforia dengan } \\
\text { penulisan } & \text { yang } \\
\text { benar } & \text { adalah } \\
\text { euforia } & \text { yang } \\
\text { berati } & \text { seseorang } \\
\text { yamg } & \text { meiliki } \\
\text { perasaan } & \text { yang } \\
\text { gembira } & \text { bahkan } \\
\text { perasaan } & \text { ini bisa } \\
\end{array}$ \\
\hline
\end{tabular}




\begin{tabular}{|c|c|c|c|}
\hline & & & lebih. \\
\hline Data 2 & $\begin{array}{l}\text { Komentar } \\
\text { @dhofira_zuhra } \\
\text { Kita semua harus berhati- } \\
\text { hati jaga adik kita karena } \\
\text { musim penculikan anak }\end{array}$ & Kita semua & $\begin{array}{l}\text { Dalam kesalahan } \\
\text { caption tersebut } \\
\text { makna nya kita } \\
\text { semua termasuk } \\
\text { kata jamak. Kata } \\
\text { ini memiliki arti } \\
\text { tersendiri. }\end{array}$ \\
\hline Data 3 & $\begin{array}{l}\text { Caption@itsmeias_- } \\
\text { Bukan ilusi jika kamu } \\
\text { nyata, kalupun nyata } \\
\text { mungkin hanya menjadi } \\
\text { ilusi semata }\end{array}$ & Ilusi & $\begin{array}{l}\text { Penggunaan kata } \\
\text { yang seharusnya } \\
\text { di ganti dengan } \\
\text { angan-angan. }\end{array}$ \\
\hline Data 4 & $\begin{array}{l}\text { Caption } \\
@ \text { kegoblogagarislucu } \\
\text { Sefruit tutorial membuat } \\
\text { lesung pipi }\end{array}$ & Sefruit & $\begin{array}{l}\text { Kata sefruit ini } \\
\text { kata penghubung } \\
\text { kalimat }\end{array}$ \\
\hline Data 5 & $\begin{array}{l}\text { Caption@aldi_triyogi } \\
\text { filososfi yang sederhana: } \\
\text { isi bukan berati ada bisa } \\
\text { jadi kosong dan kosong } \\
\text { bisa jadi ada. }\end{array}$ & Filosofi & $\begin{array}{l}\text { Kata filosofi yang } \\
\text { benar adalah } \\
\text { filsafat yang } \\
\text { berati mendasari } \\
\text { alam pikiran atau } \\
\text { suatu kegiatan }\end{array}$ \\
\hline
\end{tabular}

\section{Simpulan}

Setelah melakukan penelitian yang telah dilakukan penulis adanya kesalahan ragam gaya berbahasa pada sosial media instagram dalam caption dan komentar, maka penulis menyimpulkan beberapa hal sebagai berikut.

1. Wujud kesalahan dalam penggunaan Bahasa Indonesia di media sosial instagram yang ditemukan dalam beberapa akun sosial media instagram sebanyak 16 data. Kesalahan diantaranya 3 kesalahan ejaan, 8 pemakaian diksi, dan 5 kesalahan struktur tata bahasa. Dengan berjalannya waktu tindak tutur dalam penggunaan bahasa di instagram terjadi karena kesalahan berbahasa oleh netizen dalam konteks penulisan caption dan komentar.

2. Bentuk variasi kesalahpahaman penggunaan Bahasa Indonesia di instagram. Terdapat variasi bahasa ini menjadikan kreativitas atau keunikan dalam penggunaan bahasa. Variasi ini ditemukan dalam beberapa akun di instagram sebanyak 13 data. Kesalahpahaman diantaranya, 8 variasi bahasa Indonesia dan bahasa Inggris, 5 variasi bahasa Indonesia dengan bahasa Indonesia dengan bahasa gaul dan bahasa asing dan 
bahasa daerah setempat. Seiring berjalannya waktu dapat menurunkan kaidah-kaidah yang dalamnya. Kesalahpahaman dan tindak tutur dalam penggunaan bahasa terjadi karena penggunaan bahasa yang bebas seperti bahasa gaul dan pencampuran bahasa Indonesia dengan bahasa asing.

\section{Daftar Pustaka}

Wirahayunim, Kade. 2019. "Penilikan Kesalahan Berbahasa Indonesia yang Baik dan Benar dalam Konteks Sosial-Masyarakat Di Ruang Publik". Jurnal Penelitian dan Pengembangan Sains dan Humaniora. 3(1): 68-76. DOI. https://ejournal.undiksha.ac.id/index.php/JPPSH

Amaliah, Rosdiana Lilis. 2019. “ Ketidakefektifan Kalimat Pada Caption Instagram Mahasiswa Fakultas Pertanian Universitas Winaya Mukti”. Ilmiah Pend. Bahasa, Sastra Indonesia dan Daerah. 9(2): 67-78. DOI. https://journal.unpas.ac.id/index.php/literasi/article/view/1149

Syarifuddin, Kartika Tiara, Abdul Hafid. 2018. "Pembentukan Kosakata Baru Sebagai Bentuk Coinage Dalam Media Sosial Instagram". Jurnal KIBASP (kajian bahasa, sastra dan pengajaran). 21(1): 68-86.

Nafisah, Saidatun, Budiarso Iwan. 2020. "Pembentuk Kata Pada Istilah Khas Di Instagram Dengan Unsur Bahasa Inggris". DEIKSIS. 12(1): 75-91. DOI. https://journal.lppmunindra.ac.id/index.php/Deiksis/article/view/4466

Yuliana, Margaretha Evi, Widi Nugrahaningsih. 2019. “ Penggunaan Kata Tidak Baku di Media Sosial Instagram”. Indonusa conference on technology and social science. 1 (1): 323-327. DOI. http://www.incontecss.poltekindonusa.ac.id/index.php/files

Handono, Pambajeng Yudo. 2018. "Gaya Bahasa Berkomentar Dalam Akun Instagram( Mimi Peri Rapunchelle)". Linguista. 2(2): 97-105. DOI. http://ejournal.unipma.ac.id/index.php/linguista

Kusmantom, Hari, Harun Joko Prayitno, Dan Laili Etika Rahmawati. 2019. "Realisasi Kesatuan Berkomunikasi Pada Media Sosial Instagram @Jokowi: Studi Politikopragmatik". Parafrase jurnal kajian kebahasaan dan kesastraan. 19(2): 119130. DOI. http://jurnal.untag-sby.ac.id/index.php/parafase.

Saputra, D. A. (2016) 'Analisis Gaya Bahasa dan Moralitas dalam Novel Sala Lelimengan Karya Suparto Brata', Jurnal Program Studi Pendidikan Bahasa dan Sastra Jawa_Universitas Muhammadiyah Purworejo, 08(02), pp. 11-22. 